\title{
RELIGION AND THE SPIRITUAL CRISIS OF MODERN HUMAN BEING IN THE PERSPECTIVE OF HUSTON SMITH'S PERENNIAL PHILOSOPHY
}

\author{
Riki Saputra \\ Muhammadiyah University of West Sumatera (UMSB) \\ Email: rikisaputra.rs87@gmail.com
}

\begin{abstract}
This work is based on the assumption that modern human has undergone a multidimensional crisis. This crisis needs a timely response and an urgent solution, for if we neglect it, it will become worse and can destabilize the life of mankind globally. I refer to the work of Huston Smith on perennial philosophy to find its essence as an attempt to find solution for overcoming the modern men's crisis. This is a library research using the philosophical hermeneutics method. The paper shows that, firstly, perennial philosophy has a characteristic of metaphysics, which try to find a fundamental basis for both immanent and transcendent of all things, psychology which depicts the common sameness in human and ethics as a goal in human life. Secondly, what is meant by human spiritual crisis is a condition where human neglected even destroyed the godhead character within themselves. Thirdly, the answer made by Huston smith's Perennial Philosophy concerning human spiritual crisis include that the spiritual crisis of modern human being are seen from the tunnel metaphore, in which the basement is scientism, the left wall is education, media as the roof, and the right wall the law. The spiritual crisis of modern human being as a failure of post-modernism has a similiraty with modernism way of seeing this world as the only true reality, although there is different in approach between the two. Religious mysticism that was offered by Huston smith has a perenialistic tone. The pluralistic attitude found among humankind has to be rooted in an esoteric level within each religion. Smith's perennial philosophy is very relevant to the condition of Indonesia, which therefore has sackeled by a rigid theological dogmatism. Religion should be an endeavor for human being to find a more exalted living.
\end{abstract}

Keywords: spiritual crisis, perennial philosophy, religious mysticism

\section{INTRODUCTION}

The spiritual crisis of modern human beings here means, firstly, that they say people can no more live in hope of religion as life guidance as it prevent as well as resist progression; and secondly, that it is the believers of religion who 
do crime on behalf of God or religious teaching. Those anarchic action is not relevant to the substance of religions which educate people to create peaceful life. This is in accordance to the opinion of Frihjof Schuon that says spirituality made religion as its framework from which the absolut righteousness. This absolut righteousness contains non-temporary value on which cultural, social, and political value have their base (Schuon, 2002: 36). Seyyed Hossein Nasr insists that human being has to be aware of their function as the intermediary of heaven and earth as well as of their important position to occupy in metaphysic world as long as they are aware of the essence of trancience of their journey in this world. Human being needs to life with the awareness of spiritual reality which exists beyond their worldly nature, namely spiritual dimension. Human beings admits their humanity, admit that there is majesty as well as danger which relate to what they think and do (Nasr, 1981: 161). It is the later perspective which is referred 'human' in context of Perennial philosophy (Saputra, 2012).

Huston Smith can be classified as the key figure who developes Perennial philosophy at this time. Smith's view comes from his inquietude on spiritual crisis of modern human beings either in East or West. This condition, Smith says, was characterized by, one of them, the feeling of lost of either religious or the Transcendent within the wider firmament. The essence of that lost is very ironic, yet is very logical. As the rise of scientific world view, human being begins to see himself as the holder of the highest value in the world from which everything is measured. The meaning of life become hazy and the essence of humanity has blurred. The world losts its humanity dimension, and human being losts his control of himself (Smith, 2001: 1-2; Utsman, 2006).

Smith destructs some cosmological and social weaknesses of modernism as well as post-modernism which attempt to correct modernism. According to Smith, the achievement of modernism is limited to the scientific world view, while that of post-modernism is limited to revolution of justice. Smith in this case uses tunnel as metaphor to describe the reality of modern world long with everything within. Smith says that the ground floor of the reality tunnel is scientism which props up all other three sides. Smith says that scientism is good, but there is nothing good in the view of scientism. This is because science too condidently regards itself as one and the only reliable method to seek truth while material entity-which it deals with-is regarded as the fundamental thing existed. The left wall of the tunnel is education. Smith depicts the education of America in which scientism deceases, due to scientism in fields of social, psicological, humanity, philosphy, and religion. The roof of the tunnel is media which takes role in spreading the norrowing 
traditional world view. In the right wall there is low, represented by state, which is considered as claiming prerogative right on religion. All crisis are unifying along with the other crisis - crisis of environtment, domographic explosion, and the widening gap between the rich and poor people - when human being is facing the new millenium (Smith, 2001: 12-16). The vacuumspirituality of human being as long as Smith's view on it become an interesting topic for us to come deeper in a research. The figure who continually discusses humanity crisis and problem within the Perennial perspective is expected to be able to investigate humanity of human beings as long as to prevent the desire of violence which is regarded based on religious teaching by religious believers particularly in Indonesia.

\section{PERENNIAL PHILOSOPHY OF HUSTON SMITH.}

Perennial philosophy is very popular for intelectuals, particularly for those who are interested in religious studies and phiosophy. There are many thinkers who have contributed in this field, and Huston Smith is one of them. According to Smith, there are two distinct paradigms of philosophy, namely modern philosophy and traditional philosophy. Firstly, modern philosophy attempts to eliminate "The Sacred" or "The One" from universe of philosophy, science, and art. In fact, these three fields are indeed empty of that Holy spirit. Modern philosophy face the problem of life of human being within scientific framework in positivism sense, in which the investigation for the truth is evidenced empirically. The answer from philosophical perspective towards philosophical problem is no more attracted; the answer is rather sought from science which is regarded superior above philosophy in the old sense. For example, the newly developing trends within philosophy, such as genetical epistemology of Jean Piaget bases his epistemology on science instead of the old sense of philosophy. This is one of some developing trends which bases its epistemology on empirical world. Secondly, traditional philosophy, which is also recognized as Perennial philosophy, always discusses the existence of The Sacred or The One in whole of its manifestation, such as religion, philosophy, scince, and art (Smith, 2006: 80).

The background of Smith idea on Perennial philosophy is begun from his restlessness and inquietude on modern human being circumstances which hardly accept the pluralism within various traditions. Modern human being is still affected by those plurality, so that the agreement is a very tough condition to deliberate. According to Smith, green is not blue, however both contain light; a gold watch is not a gold ring, but both contain gold; man is not woman, but both are human; and every thing, such as combination of foot steps, is all a 
single-individual thing, but they arrange series of the unified journey (Smith, 1989: 51). To understand those pluralities, Smith provides problem solving through Perennial philosophy.

According to Smith, there are three main topic of Perennial Philosophy - he follows the formula of Aldous Huxley. The first is metaphysic which attempts to find the immanent and transcendent base of every thing. According to Smith, Perennial philosophy is ontological because it investigate Being, and Being has hierarchical character. Every hierarchical structure which exists in the world interconnects each other and culminates to transcendent or ultim reality. This ultim reality is the manifestation of the substance of the other beings which exist in the world. Transcendent reality which is called Godhead (Christianity), Tao (Taoism), Sunyata (Budhism), Brahman (Hinduism), and al-Haqq (Islam), which is the very base of every existence in the world, is an absolut-spiritual thing which can hardly be described with empirical discourse, because it transcends logic as well as verbal language. Human being can possibly have various understanding on this ultim reality. Ultim reality is opened to understood as something immanent or transcendent or even both. Human being who only depends on rationalism and positivism will see difficulties to reach substance. It is only through the pure mind or the poor in spirit the ultim reality could possibly experienced as well as understood by human being (Smith, 1989: 3-72).

The second is psicology which investigates the existence of something identical within human. Perennial psicology does not take the personal ego as the main topic rather than the eternal self or transcendent self which nest within a particular or temporary individual. Smith says, Perennial psicology insisted that the self contain duality, namely 'me-object' which is limited and 'I-subject' which within his awareness of his limitation is able to prove that he, within himself, is free of limitation. The unlimitted concept of 'I-subject' will lead human being into the deepest center of self as well as to disembarass self from the confinement of senses. The deepest of self is not soul, but rather spirit. The spirit is covered by material and is sorrounded by soul. Spirit, within the Perennial philosophy, is named trancendent reality. Therefore, transcendent reality exists not only outside of human beings but also within (Smith, 1989: 74).

The third is ethics which define the final purposes of human life. The work of Lewis, The Abolition of Man, which is quoted by Smith, insists that Perennial ethics contain the same concept as Tao. Tao is a system of value which is the unification of numbers of moral impretive from various traditions within which three goodnesses have united, namely sincerity, humility, and 
generosity. These three goodnesses is opposed by three patologies, namely arrogancy, greed, and idiocy. Humility is a capacity which create the gap between self and his individual interests, eliminating ego in order to achieve the objective and accurate vision. Sincerity is a power to recognize tools such as what Budhism call as the condition within itself, that is the condition in which they exist actually, objectively, and accurately. Generosity is seing other people as himself. This three goodnesses have great relation to the order of humanity (Smith, 1989: 75-76).

Perennial philosophy is very close to tradition and traditional chain-link, as well as is included into spiritual realization. It is this metaphysic which create the nature of religio perennis for every religion, that is the eternal religion. Metaphysic live within the heart of human being in which there is Divine Intellect, as Christianity says "there is the Kingdom of God within the heart of human being". Perennial philosophy fully pays its attention to religion within its very transcendent or metaphysic reality which is trans-historical; it see various perspectives within religion from esoteric side (substance), instead of being locked within exoteric side (form).

\section{THE SPIRITUAL CRISIS OF MODERN HUMAN BEING AS THE FAILURE OF MODERNISM}

According to Smith, modernism reduces the view on metaphysic into cosmology which is the discussion about physical or natural world. This kind of view apparently reduces the meaning of world in which human being live. For Smith, the truly metaphysic is a discourse in which every being is discussed, or is an understanding on every thing including the possibility of the existence of the other world, which science do not deals with. For that matter, while modern world view sees physical nature as every thing, the metaphysic which is discussed therein is then the cosmology itself. This modernism metaphysic is called naturalism. The serious attention of scientific method on materialquantitative thing eliminate the existence of non-material thing. Substantially, science has dissolved the transendence which is the principle element of religious metaphysic world view (Smith, 1951: 94). On the view of Smith, the general view of modernism is materialism or philosophical naturalism which only beliefs in material as the only accepted reality. Therefore, the achievement of modernism is limited to scientific-wordly view or cosmological-naturalistic one.

Smith describes the reality of modern world with the metaphor of tunnel which identifies scientism as the ground floor from which all other three stand; education as the left wall, media as the roof, and law as the right wall. 


\section{Scientism}

Smith says that scientism is good, but there is nothing good in the view of scientism. Science regards itself as the only one reliable method to seek the truth as well as it considers material as the most fundamental of being. On the other word, Smith criticizes science not because of the emergence of scientific findings which actually give benefits to people. It is the science which is very naturalistic and developes apart from the value of divinity which he criticizes. As he says:

Science in the generic sense had been around as long as art and religion. But what was discovered then-in the sisteenth, seventeenth centurieswas the controlled experiment, which escalated science to a new order of power and exactitude. That power proved to be enough to create both a new world, this world that we now live in, and a new worldview. In the process it brought many, many benefits. But in terms of worldview, in inflicted a great blow on the human psyche by making it appear that life's material side is its most important side. Now this is a logical mistake. Science didn't really say this, but because its power derived from attending to the material aspects of nature, and because that power is great and effective and gave us many benefits, the outlook of modernity is unprecedentedly materialistic (Smith, 1998: 3).

The critics of Smith towards science refers to the pattern of materialistic science which is developed by the thinkers in this modern century. This kind of pattern always says that material aspect is the only reality. Smith's attempt to criticize this pattern proposes the new perspective and awareness for science that the need for religion and spirituality should received serious attention.

\section{Education}

Smith's critics towards education in the West refers to the model of education in USA because almost of his life is spent in USA as the student, academician, and socio-religious acitivis, so that there is no part of education in USA which is absent from his investigation. According to Smith, the basic principle of the establishment of various educational institution in USA for the preacher - besides other dissiplines - is to fill the emptiness of spirituality and morality of human being. This religious climate can only last untill the modern life heading to its top (Smith, 2001: 70-80). Even though the West in the middle age was in darkness, in which human expression has no freedom do to the confinement of Church, does not mean that the emergence of modernism has to eliminate religion. Smith disagree with this kind of attitude, because the fault at that time did not belog to Church rather than some clerics who failed 
to understand the substance of his religion. Modern thinkers should be more objective to see religion. If they had done so, the lack of spirituality of human being in modern life would never have happened.

Education in USA begins to lose the dimension of spirituality because of scientism in social, psicology, humanity, philosophy, and religious discourse. According to Smith, the draw of scientism is mostly identified in social sciences. Smith's explanation on marginalization of social sciences is his agreement with the experience of Robert N. Bellah, a social thinker whose long live career was in an era in which the draw was happening. Bellah says:

"The assumptions underlying mainstream social science," Bellah writes, can be briefly listed: positivism, reductionism, relativism and determinism. I am not saying that working social scientists could give a good philosophical defense of these assumptions, or even that they are fully conscious of holding them. I mean to refer only to, in the descriptive sense, their prejudices, their pre-judgments about the nature of reality. By positivism I mean no more than the assumption that the methods of natural science are the only approach to valid knowledge, and the corollary that social science differs from natural science only in maturity and that the two will become ever more alike. By reductionism I mean the tendency to explain the complex in terms of the simple and to find behind complex cultural forms biological, psychological or sociological drives, needs and interests. By relativism I mean the assumption that matters of morality and religion, being explicable by particular constellations of psychological and sociological conditions, cannot be judged true or false, valid or invalid, but simply vary with persons, cultures and societies. By determinism I do not mean any sophisticated philosophical view, but only the tendency to think that human actions are explained in terms of "variables" that will account for them (Smith, 2001: 84-85).

According to Bellah (as quoted by Smith, 2001), most of social thinkers never think that these assumptions are in contracition to religious assumption. These assumptions are indeed very clear within themselves so that they goes beyond contradiction. Religion, because of its non-sicentific character, has no acceptable claim on reality, not even as the belief or privat action whose benefits are psicological for some people. However, these assumption are contradictory, even sharply, to whole tradition of religions and the belief of most human beings.

3. Media

According to Smith, media also has the big role to spread the reduced vision 
on metaphysic. This is pictured by, one of them, theater which media proposes through films. The script of the films are based on ideas of historians, entitled Inherit the Wind. This film talks about the relation of science and religion. The science activis is pictured as knight with armour fighting against the fool, fanatic, and fundamental religious people (Smith, 2001: 103-104).

Art has absolute right to choose and emphasize certain part to make clear the plot. As the logical consequence, the film is successful to describe clearly the opposition between the good side (science) and the bad side (religion) to community. According to Smith, the nowadays media without any doubt marginalizes religion into the valley of distrust. People of USA who still belief in God are considered meaningless. As Lasch says:

Public life is thoroughly secularized. The separation of church and state, nowadays interpreted as prohibiting any public recognition of religion at all, is more deeply entrenched in America than anywhere else. Religion has been relegated to the sidelines of public debate. Among elites it is held in low esteem - something useful for weddings and funerals but otherwise dispensable. A skeptical, iconoclastic state of mind is one of the distinguishing characteristics of the knowledge classes. Their commitment to the culture of criticism is understood to rule out religious commitments. The elites' attitude to religion ranges from indifference to active hostility. It rests on a caricature of religious fundamentalism as a reactionary movement bent on reversing all the progressive measures achieved over the last several decades (in Smith, 2001: 116-117).

Smith also gives his commentary on advertisement from which media practitioners gather their earnings. The presence of advertisements are expected to provide valuable information for people. However, in fact, those advertisements unconsciously draw people far from values of spirituality. The agens of advertisements are obsessed with capitalism which means that their motivation is money through promoting worldly-consumtive products. Media take no care on values of religion because they are regarded irrelevent with the developement of the company (Smith, 2001: 118-119).

\section{Law}

The law presented by the State claims prerogative right on religion. Smith quotes Stephen Carter on liberal American view who says that the goal of law in USA would be disturbed if the power of religion was placed along with political power. It means that Carter sees the process of relegating religion from public live. As Carter says: 
in an earlier era, although there was never as healthy a respect for religious pluralism as there should have been, I do think there was a healthy respect for what counted as religion. People might have been somewhat limited in their visions of what counted as religion, but there was a respect for it, and I think this was true right across the political spectrum and up and down the social and economic ladder. That has changed. There is less respect for religion, less of an appreciation of it as an important force that can genuinely be the motive force in people's lives without being somehow a symptom of something neurotic. That's what's been lost (in Smith, 2001: 123).

According to Smith, religion and law have to run side by side; both are inseperable. The interpretation on law in certain time always changes. If this change is not based on religious values, the law will be lack of morality. This is exactly what is happening to law in USA. For example, the case of Indian people who defended their right on their land as well as job and religion. This case took too long time, that was almost six years. The verdict apparently did not accomodate their right. Smith says that the State had oppressed weak people, the minority of Indian (Smith, 2001: 124-125).

\section{THE SPIRITUAL CRISIS OF MODERN HUMAN BEING AS THE FAILURE OF POST-MODERNISM}

Post-modernism in general criticizes reductionstic trend of modernism which see reality should be dominated, at least in term of domination of understanding. This kind of view is described by Smith as "An epistemology that aims relentlessly at control rules out the possibility of transcendence in principle". In the other words, the plot of thinking of modernism is the kind of epistemology structure which deny transcendece within its principles. Reality, in the view of modernism, is relegated into the extent of human reasoning, and is instituted within modern science. The meaning which transcends of human self and life is hardly accepted as something real, because it is not understandable by human reasoning, in fact reasoning is the standard by which every thing is controlled by modernism. According to Smith, this reductionistic trend of modernism is written clearly within the explanation models which are used by modern science. For example, the explanation has to be started from something inferior then further be moved into something superior, from 'that is less' into 'that is more'. Even more, when that superior have appeared on the surface, the goal of understanding as well as interpretation on its journey into the surface is always related to 'that is inferior' to it (Smith, 1989: 200).

The presence of post-modernism with its denial on reductionistic of 
modernism has opened the space and opportunity for reality, either for that of inferior or superior. Post-modernism proposes the chance for something whose existence used to be eliminated by modernism because it was regarded as something un-explanable by reasoning, such as morality, sense, and imagination. In the other word, post-modernism clearly objects the absolute trend of rationalism of modernism which make human reasoning-that is limited-as the determiner of the existence of reality within all of its aspects. According to Smith, post-modernism is in accordance to cultural pluralism which accept the possibility of various perspective on reality. Post modernism accepts the concept of unversalism and denies universal uniformity. Postmodernism only denies absolute claim, but unfortunately substitutes it with the other absolute claim forth. The worrying problem here is that the claim of pluralism of post-modern is too absolute, that it does not give opportunity to the existence of something which is able to inter-relate the elements of that plurality. Each element is regarded standing individually, as if it stands by and for itself.

The statement of Smith is interesting, that he says "If in ways we belong to the human race, there is the larger question of whether we likewise belong to the cosmos". Smith states that post-modernism does not find any argument to support this claim, that human is the part of cosmos as a whole. Postmodernism, as represented by deconstructionists, emphasize that there is an 'one to one' correlation between diversity in one side and injustice or justice in the other side. It makes diversity is regarded as the source of oppression, on the other hand, multiplicity is regarded as creating liberation. However, it is important to note that the anarchy and disunity as the result of that liberation would not be something pleasure. So, how could the diversity be denied, in fact that human can never be able to appreciate the difference from 'the other', if he/she does not agree that 'the other' also has the same identitas as 'the other.' However different some one is from the other, they are still same in needing for something unique (Smith, 1989: 236). Smith clearly states that modern age and its mode of thinking which tends to be scientific-rationalistic have led people into the crisis in this world, particularly for which is related to metaphyisic and religion. It is from this fact the post-modernism emerges, as the reaction for barennes of sipirituality of modern age. Post-modern is wise enough saying that science is only one of various models for interpreting universe. Post-modernism places science equal to many other kinds of interpretation mode for universe. Smith values this kind of attitude showed by post-modernism which criticizes the puzzling world view coming from modernism is appropriate, however post-modernism is forth trapped into unrational mode of thought saying that every metaphysic world view is true 
in principle (Smith, 1989: 233).

This kind of post-modernism mode of thought introduces various kind of absolute denial towards any world view, and then becomes the point of referece for many people. This will affect to the increasing number of relativistic and nihilistic values. According to Smith, the responses towards the word either from post-modernism or modernism are no different. Both sees world as the only thing real, even both are different in term of approach. Both does not accept the existence of hierarchy of reality and the other experience which transcend this wordly reality along with experience about it. Within the perspective of traditional metaphysic, Smith says that 'there is no single clearer explanation on either modernism or post-modernism other than the emphasis that the world of both are only this world' (Smith, 1989: 280).

Smith states that post-modernism does not accept that there is any world view which could be the reference point and guidance for every human's world view about universe. Refering to secularistic thought of modernism and post-modernism, it is clear that rationalism is the only epistemological tool which is used to understand the world. This rationalism could take various shapes. For example, scientific-rationalism, dialogic-rationalism, holisticrationalism, or nihilistic-rationalism. All of these whole kind of rationalism are category of secular rationalism which want to see this reality. As it has been understood that the discourse of this rationalism has limitation to see the reality and experience of the world. Secular rationalism does not have capability to understand the symptom of nature phenomena or kind of life which is related to the other reality that is higher and deeper, such as the reality of soul, spirit, and the thought of God. It is this character of post-modernism which is difficult to be accepted by traditional metaphysic paradigm which is written within religions.

Smith concludes that within post-modernism mode of thought there is no truth within reality, even more it hesitates whether the truth has meaning or not. The truth within the thought of post-modernism is problematic, therefore there have to be evaluation and change because the truth is no more regarded absolute. This failure of post-modernism is the cause for the raise of perennialism, in which Smith is named as one of central figure.

\section{MISTICISM OF RELIGION AS THE PROBLEM SOLVING OF SPIRITUAL CRISIS OF MODERN HUMAN BEING.}

Smith as the proponent of perennial uses mistical approach to understand the reality of religion and the plurality of universe as well as to investigate the root of religiousity from various kind of religion to understand the Divinity, in 
order to achieve the trancendental understanding on The One. This mistical approach of perennial is regarded as capable of explaining something authentic, related to the needed wisdom in order to apply the true model of life, which is apparently the essence of whole teachings of religion and spiritual tradition of human being. Mistical method of Smith is an experience of the presence of God within anything formulated by human being. Smith, within his works such as books, journal, and interviews of media, also states misticism with the traditional terminology, that is metaphysic and sipirtuality.

According to Smith, each of traditional, modern, and post-modern age has different world view with specific weaknesses. Traditional world view has better quality than the other two, that it is largely capable of explaining the knowledge on universe. This traditional knowledge is called spiritualmetaphysic or religious misticism; the different mode from naturalisticmetaphysic of modern science. Science has successfully described the world, however not enough to the substance of human's life within this universe. Human being has the capability of keep the universal desire of yearning which is based on the Divine. This is called the needs for metaphysics or religious misticism which is undissapearable within the life of human. This yearning transcends enterteinment, obsession, and addiction which is reflected by modernism as well as post-modernism. The yearning which is referred by Smith, appear from the deepest part of human, the yearning which attempts to release the bond of self from spaces which confines limitation and morality. This is the wide perspective proposed by traditional worldview.

Traditional perspective substantially will never decease with the presence of modernism with its naturalistic-metaphyisic mode of thought. in fact, nowadays, the power of scientism is facing the decrease of spirituality whith they can not answer, yet they needs for revitalization of traditional perspective. When human being lose their vision of life, and they are looking for answer from scientific explanation which contains of quantitative numbers, they feel empty and apparently look for the traditional wisdom. In traditional perspective, the world does not stand by itself, but rather comes from the Mighty Spirit, God, The Limitless.

According to Smith, there is fundamental difference between traditional and modernism perspective, that is, firstly, the former see spirit as fundamental, and material is derivative. In contrast to it, modernism see material as the ultimate reality and denies the other. As the second, human is the having-weaknesscreature and has desire for achieving things from He who has excess, that is God. It means that within human, there could be source of magnificence, that human is the creature or emanation of God. In contrast to modern science, it 
says that there is nothing perfect other than human. In the third, traditional perspective has faith in hope that at the end of life there will be the eternal happiness. That is not the case for modernism which ends life with sufferings without any hope for trully hapiness after life. The fourth difference is that nature and every thing therein, for traditional perspective, are full of the deep as well as large meaning whose origins are from God. On the other hand, modernism states that meaning is limited to the sensual-exoteric side. In the fifth place, traditional perspective accept the spiritual happiness, while for scientific perspective happiness is only temporal achievement for it depends on material (Smith, 2001: 34-37).

According to Smith, that deep and large knowledge is only achievable through inspiration and revelation. The epistemologies confuse to determine the source for this knowledge because knowing on this term is different from reasoning. Human's knowledge sometimes appears suddently and accidentally, and human has no capability to trace how that happens unconsciously. This kind of knowledge Smith names 'tacit knowing'. Human being has the potential of intelligence from God which actively works. The tacit knowing is openly formed through that intelligence, and it helps people to act spontanously. For example, let say a television, human could se what appears on monitor because of light. However, human does not realize that; he rather focuses onto seeing the picture on monitor without seeing light behind the appearance of the picture (Smith, 2001: 257). This Epistemology of tacit knowing of Smith can be called intuitive in terms of Western epistemology.

Smith reminds us the importance of religions to seek the same vision in seeing its duty as well as role for the world and time. Smith finds the answer within the esoteric dimension of religions. In this case, it is clear that Smith is under the influence of esoterism of religions. Esoteric have the more essential position than exoteric for religions which have faith on the eternity of spirit. The exoteric side, which is characterized by forms, shapes, or phisical, will be dissapeared, dead, and extinct with the limited nature it has. Esoteric is believed as The Eternal or The Primary. Esoteric is the holy knowledge which exists within all religions. They are all come from the same source. The believers who are able to understand it deeply will find the identical vision for each religion. Historically, human used to recognized God which is represented through symbols. God is described as gods who are mysterious, abstract, and absolute. The problem begins when human tries to represent God and his message through language. Addressing the name of God for believers is regarded as the devotion upon The Mighty God. The name of God appears in various terms, such as Yahweh (Adonai), Allah (Father), Allah, Deity, Latta, Krishna, Shifa, 
Brahman, Sunyata, etc.

In the point of view of Smith, the believers should always understand what is meant substantially by religion to recognize esoterism of religions. Human should listen to his own faith, because every legacy of faith is the limitless source. The authentic character of spirituality exists outside the ability of any body to pass through certain single religion. Even though some body put himself deeply within the religioin to which he devotes, he will always face challenge to seek the deeper experience than what he already knew, is explained, or gained. Besides, human should also listen to what other religions say. Whatever the explanation he got from the believers of other religions, he should be respectful, though it does not resemble with his own religion. Smith says 'multiple views, yes; multiple reality, no'. The view on reality could be different, however the reality itself is one, identical, and comprehensive. The variety of aspect of reality always interconnect each other. Smith proves it with the phrase 'primordial inter-connectedness', which means that there is a gift within every single human namely intuitive knowledge, as the abovementioned. The mechanism by which intuition works is different from reason, but it is this which base the mechanism of human's reason. If human's reason does the logical work based on comprehensive information which is described and defined, intuitive is hard to understand how it works. It works unconsciously but yet helps human to do things unreachable by reason (Smith, 1989: 242).

Misticism of religion of Smith is ontological or metaphysical whose focuse is being. One of its basic concept is metaphysic which recognizes divine reality which is substantial for worldly material, life, and reason. This primordia metaphysic indicates the fact that human is never be detached form the absolute dependence upon matrix of thought which produces and support human. The interest of human in this matrix is the holiest interest he could have (Smith, 1989: 52). The essence of metaphysic of misticism of religion is the hierarchical character. This character seems at glance as something rigidly and authoritatively structured, however this may not blind human eyes upon the fact that every complex structure and process relatively posseses the stable character and appears in hierarchical organization. This happen to all structures, either inorganic, organic, social organizations, or the mode of behaviors (Smith, 1989: 52-53).

Human will face difficulty to limit himself into one tradition, because it only creates the narrow understanding about universe. The attitude of understanding each other and working together could produces peace in universe. According to Smith, sometimes human does not ready to face those problems. Who is 
now ready to accept that every nations in this world is equal?. Who does not perforcely fight against his own tendency which unconsciously regards any thing different from him as inferior?. Human being who is able to listen to other people in this world will work for peace, but not peace which is based on narrow religious power or that of politics, but rather on an understanding and involvement of each other within the life of other people whose source is esoteric side of religion. It is through esoteric understanding of religion human could pay respect each other. The respect will lead into path of the higher power, namely love which is the only power capable of undermining fear, distrustfulness, prejudice, and of providing tools to create unity for people. Human being should apply the meaning of love which is commanded by their religion, because it is impossible to love other without understanding the concept of love. If people have desire of the highest faith, they have to understand the other when they are talking about their faith, and vice versa. Human being have to posses the same degree of geniality while receiving as well as giving.

The holy value and teaching of religion proposed numbers of tools on how human should behave and exploit the world, so that it does not only give benefit to human, but the ecosystems remains preserved. In fact, religions very much oppose the attitude of placing universe of object for research without paying attention to its sacredness. Smith disagree with the concept of scientific naturalism which attempts to separate the reality of nature and sacred dimension, because modern human no longer consider that nature and environtment have the sacred dimension since its creation by God. The sacredness of nature has been indeed given by God since its creation, so that human being forth have to preserve it by respecting it as being with transcendene aspect (Smith, 1976: 34).

Human being shall refer to religions and values from the sacred traditions when they are behaving as friend of this world. Religious tradition has facilitated a media by which human beings establish ethics of ecology, so that the harmonic relation between human and the world is possible. The investigation towards the world should involve several clerics and scientists, because any problem in this world is the problem which human beings share. Repositioning of the role and function of the world as the object with its sacred dimension demands a rediscovery towards the holy knowledge which help human being to realize the significance contribution of the world for the future of the life of all human being. 


\section{THE RELEVANCE TO THE HARMONY OF RELIGIOUS BELIEVERS IN INDONESIA.}

Understanding the harmony of religious believers in Indonesia through Perennial perspective of Smith is possible with two approaches. The first approach is education, particularly that is related to character building or religious education. Religious education has to be managed comprehensively. In the basic and advance level, the student should receive religious education within which the basic concepts of religions along with the practical aspects based on each religion are taught. Educational institution managing secular dissipline should hold religious education in accordance to the religious belief of the student. The student has to be taught about the existence of other faith other than their own, and as human being those who has different faith remains human to respect. If those basic values is growing, the harmony between religious believers will be ease to achieve (Kuswanjono: 2006: 95).

This approach is already applied in educational system in Indonesia, however is not maximum enough, particularly for secular school. For example, religious lesson for elementary, junior high, as well as senior high school, has very limited amount, that is once a week. This fact reflects the failure of government to create the substantial understanding of religion for student. On the other hand, religious educational institution such as Madrasah Tsanawiyah, Aliyah, Pesantren, and the likes alredy have good amount or religious disciplines such as aqidah, akhlak, fiqh, ushul fiqh, etc. This is also happen for religious educational system other than Islam in Indonesia. A deep investigation on religious lessons taught within those religious educational institution, there could be an insight that the religion is expressed exclusively and concervatively, particularly which deals with the issu of rahmatan li al'alamin and the relation of religions each other. For example, the discipline of aqidah (theology, kalam), the student only receives one perspective/mazhab, that is asy'ariyah among many other perspectives. This fact unconsciously lead the student into the exclusive mode of thought and the denial towards the different understanding. Unfortunately, that is also the case sometime for the teacher, who acts as the provocator to get across his brother/sister within the same religion whose understanding is different even more his brother/sister with different religious belief rather than to promote peaceful life within the plurality of religious faith.

In higher education level, religious education besides contains curriculum about their own faith (normative doctrines), the student also have to deal with the issue of critical studies towards religion in which historical criticism is applied. The student has to understand that plurality is the historical fact and 
every religion is one peace of puzzles which systematically ordered as paths to the Divine truth. This plurality awareness would lead into tollerance among religious believers (Kuswanjono, 2006: 96). What happens to the elementary and junior-senior high school, as the above-mentioned, unfortunately also happens to higher education. Religious subject only have two sks among whole courses of study. The other weakness can also be identified from the unability of teacher/lecturer to understand the substantial aspect of religious teachings, particularly about the inter-relation of religions. In fact, it is the teacher/lecturer who acts as the provocator to trigger conflict within religion.

It is the opportunity for government to perform immediat act to add the other amount of SKS (credit system for the curriculum used in Indonesia) for religious subjects, particularly for either state or private school. Those educational intitution have to substitude the curriculum of religious studies with what is rellevant to the spirit of each religion. On the other hand, the mechanism of recruitment for new teacher has to be more selective, beside there is also the need for routine evaluation from leader committee of such institution. For extraculicular agenda, the teacher has to initiate the interreligious pesantren. We see this as the critical agenda to build the togetherness of religions. Our argument is supported by our experience of holding that kind of agenda hosted by Forum Kerukunan Umat Beragama (FKUB) of Padang which involved students as the participant.

The second approach is the dialogue between religious believers. Perennial proposes a method of dialogue which is capable of bridging the existence of truth claim as well as the claim for exclusive salvation which generally emerges within religion, namely phenomenology of religion. This is the method by which the existence of religious plurality with appreciation rather than domination or claim for apostasy. This method eleminates the exclusive view for other religion by respecting other. This method avoids to seeking fallacies of other rather than understanding the perspective of other to strenghten his own faith. This method guides the believers of religion to be humble and honest by which seeing other religion with the perspective, attitude, and faith of its believers is possible (Kuswanjono, 2006: 96). If the clerics have the thought by which he hates and therefore contempts believers of other religions, the substantial dialogue will never happen. Religion has no more power to propose guidance to fix civilization of human beings; it rather be the trigger for permanent conflict.

Perennial of Smith finds a peace and mutual understanding within religious behavior, because it creates the awareness of tollerance and never opposes the exoteric differences of religions. The concept of Perennial of Smith is very 
relevant to be the reference for Indonesian religious believers who used to be trapped within the cage of rigid-exclusive theology. This approach is not trapped within the cage of formal, exoterical, or symbolical context which are basically is hard to unify; it rather investigate the substance or esoteric side of religions. At this point, religion can be a media and instrument for human being to achieve valuable life. On the other words, it is the religion for human instead of human for religion. The later will create exclussive and intollerance attitude. This kind of attitude change the religions which basically is humanitarian into dehumanitarian. The best is the former, that religion for human. This implicitly says 'serve religion for the good of human'. Human is every thing whose right is to be defended, not God - borrowing the phrase of Gus Dur, "God does not need to be defended." Because the religion for human, every religion must contain doctrines on humanity. According to John Hicks, the difference of religions come from the different interpretation of human being towards religion and God because the burden of local custom. The essence of religion is one, it is interpretation which differs.

Cak Nur says that even though the religion of Moses is Jewish and that of Jesus is Christiaity, however the essence of those religion are islam, that teach th devote to God. Cak Nur differ 'general Islam' to 'specific Islam'. General Islam is the religions brought by the prophets before Muhammad, who were sent down to human being any time any where, while specific Islam is Islam which is brought by Muhammad and the consistence of general Islam as the teaching for human being which is completed and perfected. For Cak Nur, Pancasila is the common platform (kalimatun sawa') from various plurality of religions of Indonesia. Religiousity which is needed to develop is al-hanifiyyat al-samhah, that is the act of seeking the wide truth, tollerance, without fanaticism which confines soul (Madjid, 1995: xiv; Hakiki, 2016).

I argue that applying Perennial of Smith in Indonesia is never free from weakness and strength. The first strength is the possibility to create the peaceful life among religious beliefs. Perennial of Smith is able to investigate each religious teaching deeply into the root that the basic teaching of all religions are mutual goodness, the hight tollerance even though from various concept. The second is that it rebuild the awareness of Indonesian people which already has the philosphy of Bhinneka Tunggal Ika or the concept of pluralism. Perennial of Smith view human being comprehensively, that is between which is theoritical and practical, between mind and attitude. The third is related to science and religions which characterized as preventive. The scientists of Indonesia still hold onto religious metaphysics within their ijtihad. Ahmad Baiquni, as a first physician of Indonesia, consider religion as the support and 
guidance of human being in his adventure within this world. This is evidenced by his works which as Muslim, he explain universe quoting several words of God to suppor scientifical preposition which is deduced through reason. That also happen to educational system of Indonesia, in which many universities preparing the religious-scientist student such as the shift of Institut Agama Islam Negeri (IAIN) to Universitas Islam Negeri (UIN) from which secular faculty is pioneered, or Christians university such as Universitas Kristen Duta Wacana (UKDW), etc.

The fourth is that perennial of Smith is capable enought to prevent traditional credence sect in Indonesia. We argue that those credence sects are not religion, even more the legalized religion in Indonesia. We agree with Gusdur saying that the emergence of those sects reflects the failure of hierarchy and structure of big religions of Indonesia in providing problem solving for fundamental social problems within community nowadays. On the other words, these sect emerge from those big religions from which the new spiritual sect arises without religion. Perennial of Smith denies spirituality without religion because principally religions contain spirituality. Substantially, this kind of failure happens because the believers of religions does not able to rich the spirituality of religion he has faith in. This is what Perennial could solve, to replace those credence sect into its prime religions which is legalized in Indonesia.

Beside of those strength, Perennial of Smith also contains weaknesses. The first is that the material of Smith's perennial is very tough that it contain symbolic language which is only understandable for certain people. The second is that the core of Perennial of Smith relate to the sensitive part of religiousity particularly for those who has radical and fundamental mode of thought, becuase the substance of Smith's perennial is to harmonize religions and to promote tollerance on the differences of those religions. The third is that the spiritual experience of Smith who practice all religious rituals such as attending worship in Church, praying five times a day, vendata tradition of Hinduism, and zen tradition of Budhism routinly is hard to explain to Indonesian religious believers. Smith performs almost whole ritual of religions due to his desire to achieve practically the common vision of religion to rich God. We say that it is this common vision what Smith want to show to religions believers in context of how to behave before the other religions, while those spirituality tends to be persolan; the spirituality of Smith does not have to be absolutely followed. This is the distinction of Huston Smith's Perennial to that of Frithjof Schuon, Seyyed Hossein Nasr, ect.

Perennial of Smith is antroposentric with the concrete way, that is theoretically 
deepen the concept of religious teaching as well as tradition. While practically, it suggests religious believers to perform their religious ritual along with other religious tradition in order to be the trully religious believers. Perennial of Schuon share Smith's mission on antroposentric, but different enough in term of approach. The difference is only on personal experience on religious ritual they do. Schuon for the first time was as Smith, that he performed ritual of all religions, however since 1965 Schuon decided to choose one religious vision, that is Islam and changed his name into Isa Nuruddin. Perennial of Nasr is theocentric because the first time consistent to Islam, and his perennial tend to investigate the tradition within Islam itself.

Aside these various kind of strengths and weaknesses, philosophy of perennial of Smith remains possible to be referred as optimistic view in order to anticipate as well as to solve critical problem of spirituality of modern human being, particularly in Indonesia. This perennial is expected as capable of actively playing its role to seek the true substantial understanding of religion and to reform the anarchism of religions which is increasing within inter-religious interaction. Various approaches has been applied so far, but not effective enough. It is now time for Perennial to solve the problem of spirituality of human being, eventhough the solution from perennial could not instantly applied as much as scientific ijtihad.

\section{CONCLUSSION}

Perennial of Smith finds peace and mutual understanding within religious behavior, because it suggests awareness of tollerance and does not oppose the exoteric differences of religions. The concept of Smith's perennial is proper to be the reference for religious believers of Indonesia, who so far trapped within the rigid theology. This approach is not caged within formal, exoteric, as well as symbolic context, but it rather investigates ths substance or esoterical aspect of religion for human beings. At this point, the religion could be as the media or instrument for human to achieve valuable life. On the other words, it is the religion for human rather than human for religion. The later will create intollerance and exclusive religiosity by which the religions could change its humanitarian nature into dehumanitarian. It substantially should be religion for human. Thi implicitly says 'serve religion for the good of human'. However, philosophy of perennial at the end has to face sacred reality which is hard to understand because it sacredness is beyond language. There is a objection for the truth of perennial. Philosophy of perennial is only considered as the mode of thinking which provides unaccepted truth. This does not mean to be pesimistic on the weakness of philosophy of perennial. Philosophy of 
perennial as knowledge is only limited to its alternative proposals to achieve God's message. The absolute truth remains God possession which is hard to achieve by human being who life in this worldly life.

\section{REFERENCES}

Hakiki, Kiki Muhammad. 2016. "Islam dan Demokrasi: Pandangan Intelektual Muslim dan Penerapanya di Indonesia." in Wawasan. Vol. 1. No. 1. P: 1-17.

Kuswanjono, Arqom. 2006. Ketuhanan Dalam Telaah Filsafat Perennial: Refleksi Pluralisme Agama di Indonesia. Yogyakarta: Filsafat UGM.

Nasr, Seyyed Hossein. 1968. Man and Nature: The Spiritual Crisis of Modern Man. London: Unwin Paperbacks.

1981. Knowledge and the Secred. New York Albaby: State University of New York Press.

Saputra, Riki. 2012. Tuhan Semua Agama: Perspektif Filsafat Perennial Seyyed Hossein Nasr. Yogyakarta: Lima.

Schuon, Frithjof. 1997. Hakikat Manusia (Translation by Ahmad Norma Permata). Yogyakarta: Pustaka Pelajar. 2002. Form and Substance in the Religions. Canada: World Wisdom.

Smith, Huston. 1976. The Common Vision of the World's Religions: Forgotten Truth, HarperSanFrancisco, New York.

1989. Beyond The Post-Modern Mind. USA: The Theosophical Publishing House.

1998. The World's Religions: Our Great Wisdom Traditions. New York: PerfectBound.

2001. Why Religion Matters: The Fate of The Human Spirit in an Age of Disbelief. New York: Harpers Collins Publisher.

2006. A set at The Table: in Coversations With Native Americans on Religious Freedom. Berkeley: University of California Press.

1951. "The Operational View of God: A Study in the Impact of Metaphysics on Religious Thought." in The Journal of Religion. Vol. 31, No. 2, retrieved on 07 April 2011.

Utsman, Sabian. 2006. "Konsep Manusia Menurut Marx." in Jurnal Studi Agama dan Masyarakat. Vol. 1. No. 1. P: 1-11. 